\title{
Testing the Bonds of Solidarity in Europe's Common Citizenship Area
}

\author{
Jo Shaw
}

The European Citizens' Initiative proposing the extension of voting rights for resident non-national EU citizens to all elections in the host state is an important and timely initiative. It is to be hoped that it will bring the key question about the normative and practical consequences of the development of the EU as a 'common citizenship area' to the centre of attention. As David Owen's contribution makes clear, the EU struggles with the challenges posed by the question of 'who should vote in which election where' because it is nestled - as a type of special purpose vehicle for the varied projects clustered under the heading of European integration - somewhere between the 'truly' federalised polity and the 'purely' intergovernmental association. The creation of EU citizenship and the remodelling of the treaties according to the 'Lisbon' schema do not provide a definitive normative answer to the question of how voting rights should be organised within this mixed polity in which the states remain significant actors. At the same time clearly the practical consequences of the exercise of free movement demand some sort of response - from the EU institutions and from the member states - to the 'democratic wrong' (as Owen puts it) that arises because many of those who exercise their right to free movement end up, in one way or another, being disenfranchised in relation to all of the elections not covered by Article 22 TFEU, unless they choose the often costly and cumbersome route of acquiring the citizenship of the host state or are lucky enough to have the citizenship of one of the member states which impose no conditions upon the exercise of external voting rights.

Accordingly, I'm instinctively sympathetic to the ECI proposal, and will be happy to sign it, because it seems to me that this would be one of the most effective ways in which this important issue could finally receive the attention it deserves.

Somehow, despite its centrality as the core foundation stone of EU citizenship (even if EU citizenship has a broader constitutional and political potential that has yet to be realised), free movement still tends to be marginalised as a topic within popular and political debate in the member states. 
The European Commission attests to this when it draws attention to the increasing number of complaints that it hears about via the SOLVIT and the Your Europe Advice systems from aggrieved citizens deprived of the rights that they are currently accorded (e.g. in local or European parliamentary elections), or unable to comprehend why the existing system does not protect them in respect of what is still regarded as the 'gold standard' of political participation, namely the right to vote in national elections. It is indeed reasonable to ask, as does Andrew Duff, why - if persons are mobile they suddenly seem, as regards national elections, to come out from under the protective umbrella provided by Article 3 of Protocol 1 of the ECHR governing the obligations of states to organise free and fair elections for legislatures on the basis of universal suffrage.

But for years, the issues of free movement and the rights to which it does, or does not, give rise have rarely been discussed in the media or in popular political discourse. And now that free movement does receive more attention, it is not always welcome. Many host member state governments are too quick to say that free movers can get access to too many rights because apparently they have an unimaginable propensity for 'benefit tourism'. It does seem reasonable to suggest that if the host state's political community were balanced by the presence of socially, politically and economically integrated free moving tax-payers these types of arguments might gain a little less traction within the body politic. It has been clear since 2004 that for some member states the consequences of the free movement of labour are now more closely aligned to mainstream debates about immigration than to debates about the meaning of EU citizenship and the about the constitutionalisation process of the European Union.

But generally speaking, the member states take depressingly little care to ensure that within the 'common citizenship area' the citizenship experience is good for either their own citizens who are mobile or for the citizens of other member states who are resident (or in some other way subject to the jurisdiction of the host state). For over the life course, the incidence of mobility is actually much higher than is the case when we count only those who reside in another member state at any given time. Much larger numbers of persons are thus affected directly or indirectly than tends to be assumed. So, in a way, it is good to reinforce the point that solving this particular democratic problem in the EU and its member states is going to require concerted action at both the EU and the member state levels. It cannot be solved at one level, without thinking about the implications at the other 
level. And no solution is simple. All have significant practical consequences or caveats.

Certainly, it is impossible to think about the issue of voting rights for EU citizens without considering its implications in relation to national citizenship. Rainer Bauböck thinks that the proper democratic approach is to make national citizenship much more open to all long term residents who lack it, but who would like to make a sufficient commitment to be entitled to vote. He sees the two things as going hand in hand. But Bauböck also wants to ensure that national citizenship is equally open to EU citizens and to third country nationals. Given the current trend in many states to heap more and more conditions on those acquiring citizenship by naturalisation, unfortunately his wish to use this route towards democratic equality is as far away from political reality as the desire to see EU citizenship rights extended by treaty amendment to include the right to participate in host state national elections. Perhaps more realistic could be a push towards a more generalised acceptance of external voting within the EU, but while this route could potentially offer an avenue for all to participate in one set of elections, it does not necessarily let them participate in the one that they would choose. In other words, from a truly European perspective, both of those routes, which prioritise national solutions over supranational ones, do seem suboptimal.

Moreover, they might also seem suboptimal because they assume that the only way of ensuring that democratic participation is not undermined by the use of free movement rights involves direct attempts to persuade the member states either to change their national laws on citizenship and/or external voting in a coordinated way, or to agree - as 'masters' of the treaties - to change the terms of EU citizenship itself. In fact, if member states recognised more readily their responsibilities in respect of the common citizenship experience for both outgoing and incoming EU migrants, they might be readier to change their national laws autonomously, or perhaps in concert with other states which provide reciprocity of rights, in order to build a more substantial common electoral area akin to the one that already exists in part between the UK and Ireland. One could then even imagine the circumstances in which the states could agree, with the assistance of the EU institutions, on a facilitative convention structuring these types of reciprocal citizenship relationships.

But the member states should not be the sole focus of attention. It seems to me that the debate about the character of the common citizenship area 
should be held in conjunction with wider public deliberation about how, and whether, the EU should generate the types of closer bonds of solidarity that seem necessary for the purposes of solving the euro crisis or facing down environmental challenges in the future. In that respect, the ECI should be seen as one strategy alongside others, such as political campaigns at the national level and strategic litigation testing out the potential limits of EU citizenship or the effects of the ECHR. All of these steps are needed to raise awareness of this very important issue.

Open Access This chapter is licensed under the terms of the Creative Commons Attribution 4.0 International License (http://creativecommons.org/licenses/by/4.0/), which permits use, sharing, adaptation, distribution and reproduction in any medium or format, as long as you give appropriate credit to the original author(s) and the source, provide a link to the Creative Commons license and indicate if changes were made.

The images or other third party material in this chapter are included in the chapter's Creative Commons license, unless indicated otherwise in a credit line to the material. If material is not included in the chapter's Creative Commons license and your intended use is not permitted by statutory regulation or exceeds the permitted use, you will need to obtain permission directly from the copyright holder.

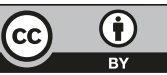

